\title{
Rotation of Dioscorea rotundata cv Habanero with D. alata cultivars for the control of dry-rot disease ${ }^{1}$
}

\author{
Domingo Oramas-Nival ${ }^{2}$ and José A. Rodriguez ${ }^{3}$
}

J. Agric. Univ. P.R. 86(3-4): 123-130 (2002)

\begin{abstract}
A field study was conducted at the Corozal Agricultural Experiment Substation to evaluate the effect of rotation of Dioscorea rotundata cv Habanero with $D$. alata cus Kinabayo, Florido and Gunung on the incidence of Pratylenchus coffeae and dry-rot disease. For the first cycle, experimental plots were planted with cvs Kinabayo, Florido and Gunung and with cv Habanero, with and without nematicide ( $33.62 \mathrm{~kg}$ aldicarb $10 \mathrm{G} / \mathrm{ha}$ at planting). For the second cycle, all plots were planted with cv Habanero. The results of the first cycle showed a higher population of $P$. coffeae in plots planted with $\mathrm{cv}$ Habanero than in plots with the $D$. alata cultivars. In this cycle, the quality of cv Habanero yams was significantly reduced by dry-rot when compared to the quality of cvs Kinabayo, Florido or Gunung. In the second cycle, the quality and yield of the $\mathrm{cv}$ Habanero yam tubers improved significantly in plots rotated with $D$. alata cultivars, as compared to quality and yield in plots under continuous planting of cv Habanero, with or without nematicide.

Key words: Dioscorea rotundata, D. alata, Pratylenchus coffeae, dry-rot, management, nematode control, rotation, yam
\end{abstract}

\section{RESUMEN}

Rotación de Dioscorea rotundata cv Habanero con D. alata para el control de la pudrición seca del ñame

Se realizó un estudio de campo en la Subestación Experimental Agrícola de Corozal para evaluar el efecto de la rotación de $D$. rotundata cv Habanero con D. alata cus Kinabayo, Florido y Gunung sobre la incidencia de $P$, coffeae y la enfermedad de pudrición seca. En el primer cicio las parcelas se sembraron con los cultivares Kinabayo, Florido y Gunung y con el cv Habanero, con y sin nematicida $(33.62 \mathrm{~kg}$ aldicarb $10 \mathrm{G} / \mathrm{ha}$ al momento de siembra). En el segundo cíclo todas las parcelas se sembraron con el cv Habanero. Los resultados del primer ciclo mostraron una densidad poblacional de $P$. colfeae significativamente superior en las parcelas del cv Haw banero en comparación con las parcelas de los cultivares $D$. alata. En este ciclo, fa calidad del cv Habanero se redujo significamente debido a la pudrición seca en comparación con la calidad de los cvs. Kinabayo, Florido y Gunung. En el segundo ciclo, la calidad y el rendimiento de los tubérculos

'Manuscript submitted to the Editorial Board 20 August 2001.

"Assistant Nematologist, Department of Crop Protection, Agricultural Experiment Station, University of Puerto Rico, Box 21360, San Juan, P.R. 00928

"Agronomist (Retired), Depariment of Agronomy and Soils. 
del name Habanero aumentaron significativamente en las parcelas rotadas con cultivares de $D$. alata, en comparación con la calidad y el rendimiento de las parcelas donde el cv Habanero se sembró en forma continua, con y sin nematicida.

\section{INTRODUCIION}

The Guinea or African white yam, Dioscorea rotundata $(\mathrm{L})$ Poir, had its origin in West Africa where the word "yam" is almost synonymous with D. rotundata (Martin and Sadik, 1977). In Puerto Rico, D. rotundata is usually preferred to other species because of its culinary and tuber characteristics, such as acceptable coolking appearance (white, appetizing and flavorful flesh) and uniformity of cylindrical tubers. The commercial African white yam cultivars primarily marketed in Puerto Rico are the Guinea or Habanero and the Guinea Negro yams. Local prices of these cultivars are higher than those of any other cultivars or species. In 1990 , the local production of yam was $10,524 \mathrm{t}$. Yield production declined from that year down to 3,664 $\mathrm{t}$ in 1999 (Dept. Agric., 2001).

The attack of nematodes, especially Pratylenchus coffeae (Zimmerman) Filip. \& Schuurmans Stekhoven, on D. rotundata (Oramas et al., 1990) and the adverse effects of anthracnose disease caused by the fungus Colletotrichum gloeosporioides Penz on the Florido (D. alata) cultivar (Mignucci et al., 1988) are among the most damaging pathological factors contributing in part to the reduced production of yam in Puerto Rico. Pratylenchus coffeae affects $D$. rotundata production by attacking the cortical tissue of tubers, thus causing dry-rot lesions that reduce quality and viability (Acosta and Ayala, 1975). The disease was first described by West (1934), who named it dry-rot disease. In Puerto Rico the disease may cause yield losses as high as $98 \%$ in fields highly infested with P. coffecte (Román et al., 1980).

Lacal control management of $P$. coffeae in yam depends on the use of chemicals or leaving the land uncultivated for one or more growing seasons. Pesticides, in addition to their high cost, have been under evaluation for new safety regulations to provide greater protection to human health and the environment (USEPA, 1996). lt is neither economical nor practical for farmers to keep the land in fallow (NAS, 1980; Roman, 1978). In spite of the fact that monoculture of D. rotundata reduces yields, on the basis of their growing and marketing experience, growers favor planting the same crop year after year on the same land. A possible alternative that could permit growers to continue this practice without detrimental effect on the crop and income is the rotation of susceptible and resistant Dioscorea species to control $P$. coffeae. Ayala and Acosta (1971) reported that $D$. alata cv Florido did not seem to be very susceptible to nematodes. In 1991, we observed that $D$. alala cvs 
Binuga and Gunung, and D. esculenta were resistant to $P$. coffeat (D.O.N. \& J.R.G., unpublished data). In the same year, P. coffeue was isolated from $1.00,1.00,50$ and $17.6 \%$ of cortical tissue and surrounding soil samples from $D$. rotundata, $D$. trificla, D. cayenensis and $D$. alata, respectively (D.O.N. \& A.G.V., unpublished data). Among these species, D. rotundata and D. alata are the most valuable in Puerto Rico. In spite of the fact that some D. alata cultivars have been fornd associated with $P$ coffeac, the number of isolated nematodes was generally low. There appear to be no published records of yam rotation studies to control $P$. coffecte in this crop. With these facts in mind, we conducted the present study to determine the effect on the incidence of $P$. coffeac and dry-rot disease of the contimuous planting of D. rotundata cv Habanero in rota. tion with $D$, alata yam eultivars.

\section{MATERIALS AND METHODS}

A field experiment was established in a Corozal clay (Ultisol) soil at the Agricultural Experiment Substation of Corozal located in the east central mountain region of Puerto Rico. The site selected was infested with $P$. coffecue and had heen planted with Habanero yam for more than five years. The experiment consisted of two planting cycles. The first cycle was established 19 March 1992 and harvested 332 days later. The second was initiated 20 April 1993 and harvested 286 days afterward. The duration of the experiment was about two years, including two months of dormancy. Yam takes about eight to 10 months until harvest, followed by a dormancy period of about two months (EEA, 1997). For the experiment, three D, alata cultivars (Kinabayo, Florido and Gunung) and one D. rotundata (Habanero) were used.

Tuber pieces of approximately $230 \mathrm{~g}$, free of dry-rot disease, were immersed in 2,400 $\mathrm{mg} / \mathrm{L}$ of oxamyl $\mathrm{L}$ for $15 \mathrm{~min}, 24$ hours before planting. Seeds were spaced at $0.40 \times 1.22 \mathrm{~m}$ in $2.4 \times 4.6 \mathrm{~m}$-plots, equivalent to 18,939 plants per hectare. Five treatments, replicated five times, were arranged in a randomized block design. For the first cycle the treatments were plots planted to: 1) Kinabayo, 2) Florido, 3) Gunung, 4) Habanero, and 5) Habanero with a nematicide. For the second cycle, all plots were planted to the Habanero cultivar, including the check with the nematicide. Aldicarb $10 \mathrm{G}$ at $33.6 \mathrm{~kg} / \mathrm{ha}$ at planting time was used only in the plots of Habanero with nematicide. Cultural practices and control of weeds and diseases were as recommended for the crop (EEA, 1997). At harvest, plants were removed and the tubers dug up, rated on a scale of 0 to 100 percent of cortical dry-rot damage, and weighed by group in four categories. The categories were the following: 1) excellent quality ( $0 \%$ dry-rot); 2) high quality (1 to $25 \%$ dry-rot); 3 ) 
medium quality (26 to $50 \%$ dry-rot); and 4) poor quality (51 to $100 \%$ dry-rot). During the harvest, two yam samples were taken at random from each plot, and twenty-five grams of their cortical tissue was comminuted in a blender, and processed by the method of Christie and Perry (1951) to determine $P$. coffece population. Data were analyzed statistically by ANOVA for analysis of variance and means separated by Duncan's Multiple Range Test (Cody and Smith, 1997).

\section{RESULIS AND DISCUSSION}

\section{Nematode population dynamic}

Table 1 shows the number of $P$. coffeae isolated at harvest from the cortical tissue of yam tubers in the first cycle of the experiment. In this cycle, the D. alata cultivars, Kinabayo, Florido and Gunung, had the lowest infestation of $P$. coffece with 0,170 and 80 nematodes per $100 \mathrm{~g}$ of roots, respectively. In contrast, the Habanero cultivar, both with and without nematicide, showed the highest populations of $P$. coffeae, with 42,248 and 22,676 nematodes per $100 \mathrm{~g}$, respectively.

In general, population of $P$. coffeae in plots of $D$. alata cultivars was less than $1 \%$ of the population in plots of $D$. rotundata. This result confirms the resistance of $D$. alata to $P$. coffeae reported by Ayala and Acosta (1971) and by Oramas and Rodríguez (1991). Yams of the Habanero cultivar from nematicide-treated plots showed a higher number of $P$. coffeae than yams from non-treated plots. We have no experimental evidence to explain this difference in nematode population. However, considering the fact that nematicides protect the crops for the four- to five-month period after treatment, with a drastic increase in nematode population thereafter (Román and Badillo, 1965), we theo-

TABLE 1.-Mean number of Pratylenchus coffeae in the cortical tissue of four yam cultivars after first cycle of a rotation experiment with $\mathrm{D}$. alata and D. rotundata cultivars.

\begin{tabular}{lc}
\hline Treatments & P. coffeae $/ 100 \mathrm{~g}$ \\
\hline Kinabayo & $0 \mathrm{c}^{2}$ \\
Florido & $170 \mathrm{c}$ \\
Gunung & $80 \mathrm{c}$ \\
Habanero & $22,676 \mathrm{~b}$ \\
Habanero/N & $42,248 \mathrm{a}$ \\
\hline
\end{tabular}

\footnotetext{
${ }^{1}$ Kinabayo, Korido, and Gunung $=D$, alata; Habanero $=D$, rotundato; Habanero $\mathbb{N}=$ Habanero with aldicarb $10 \mathrm{G}(33.62 \mathrm{~kg} / \mathrm{ha})$.

${ }^{2}$ Means in the same column followed by a common letter do not differ significantly at $\mathrm{P} \leq$ 0.05 according to Duncan's Multiple Range Test.
} 
rize that the nematicide protection to treated plots provided a suitable and better cortical environment for a higher nematode buildup. This theory is in line with the yields, which showed lower weight and better quality of the treated vs. non-treated plots as demonstrated by the lower yield of tubers observed within the 26 to 50 percentage of dry-rot damage ('Table 2). The higher number of nematodes in nematicidetreated plots was not sufficient to cause detriment in yield, as the difference in excellent and high quality tubers in the two treatments was not significant (Table 2).

Nematode samples of the second cycle showed the tendency of $P$. coffeae to increase when Habanero cultivar was planted. However, samples were partially lost and those data are not included here. Thus, only yield vs. dry-rot damage was used to show the rotation effect in this cycle.

\section{Yield and dry-rot damage}

For the first cycle, the Gunung cultivar had the highest yicld of excellent quality tubers (Table 2). The high productivity behavior of the Gunung cultivar has been established in previous studies (GonzálezVélez and Santiago-Córdova, 1989; Hepperly and Vázquez, 1989). This cultivar was followed by the Florido and Kinabayo cultivars. These $D$. alata cultivars produced no dry-rot-damaged tubers nor did they have typical symptoms of nematode damage.

This observation corroborates the low incidence of $P$. coffece isolated from the tissue of the three cultivars of D. alata (Table 1), all of which confirms their resistance to the lesion nematode and the dry-rot dis-

TABLE 2.-Mean yield of Dioscorea alata and D. rotundata cultivars grouped by dry-rot damage after the first cycle of a rotation experiment.

\begin{tabular}{lcccc}
\hline & & \multicolumn{2}{c}{ Yield (t/ha) $^{\mathrm{t}}$} & \\
Treatment & Excellent & Figh & Medium & Poor \\
\hline Kinabayo & $14.57 \mathrm{~b}^{3}$ & $0.00 \mathrm{~b}$ & $0.00 \mathrm{c}$ & $0.00 \mathrm{~b}$ \\
Florido & $18.51 \mathrm{~b}$ & $0.00 \mathrm{~b}$ & $0.00 \mathrm{c}$ & $0.00 \mathrm{~b}$ \\
Gunung & $40.36 \mathrm{a}$ & $0.00 \mathrm{~b}$ & $0.00 \mathrm{c}$ & $0.00 \mathrm{~b}$ \\
Habanero & $2.60 \mathrm{c}$ & $3.34 \mathrm{a}$ & $2.60 \mathrm{a}$ & $2.40 \mathrm{a}$ \\
Habanero/N & $5.46 \mathrm{c}$ & $1.80 \mathrm{ab}$ & $1.14 \mathrm{~b}$ & $1.30 \mathrm{a}$ \\
\hline
\end{tabular}

${ }^{1}$ Quality Groups: Excellent $=0 \%$, High $=1$ to $25 \%$, Medium $=26$ to $50 \%$, Ponr $=51$ to $100 \%$.

${ }^{2}$ Kinabayo, Florido, and Gurung $=D$. alata; Habanero $=$ D. rotundatr $;$ Habanero $/ \mathrm{N}=\mathrm{Ha}$ hanero with Aldicarb $10 \mathrm{G}$ ( $33.62 \mathrm{~kg} / \mathrm{ha})$.

${ }^{3}$ Means in the same column followed by a common letter do not differ significantly at $P \leq$ 0.05 aecording to Duncan's Mulliple Range Test. 
ease. The Habanero plots, both with and without nematicide, produced a significantly lower yield of excellent quality tubers and more poor quality tubers. D. rotundata dry-rot-damaged tubers represented 43 and 76 percent of total yield in the Habanero treatments with and without nematicides, respectively. There were more medium quality tubers in the Habanero plots without nematicide than in the plots with nematicide.

Table 3 shows yield of cv Habanero for the second cycle. Significantly higher yields of excellent quality yam tubers were observed in plots rotated with $D$. alata cultivars than in plots under continuous planting of cv Habanero. The rotation effect on the yam tubers was more evident when excellent and high quality and medium and poor quality tuber's were combined as marketable and non-marketable tubers, respectively (Table 4). Yield of marketable tubers from plots rotated with $D$. alata cultivars was significantly higher than that from plots where no rotation was used. The opposite was true for non-marketable tubers. It was also observed that yields of plots under continuous planting of $\mathrm{cv}$ Habancro, with and without nematicide, were lower in the second cycle than those of the first cycle. On the contrary, yields of medium and poor quality tubers were higher. This result was an effect of the residual population of nematodes left and accumulated in the soil after the consecutive planting of the Habanero yam.

In the second cycle, non-marketable tubers represented yield losses of 71.8 and $66.8 \%$ in plots under continuous culture of $D$. rotundata, with and without nematicide. In the first cycle yield losses of 45.7 and $25.1 \%$ had been obtained in the same plots. These numbers repre-

TABLE 3.-Mean yicld of Dioscorea rotundata grouped by dry-rot damage after the second cycle of a rotation experiment with yam eultivars.

\begin{tabular}{lclll}
\hline & \multicolumn{4}{c}{ Yield (t/ha $)^{2}$} \\
\cline { 2 - 5 } Treatment & Excellent & High & Medium & Poor \\
\hline Habanero $(\mathrm{K}-\mathrm{H})$ & $7.78 \mathrm{a}^{3}$ & $1.89 \mathrm{a}$ & $1.98 \mathrm{bc}$ & $3.32 \mathrm{bc}$ \\
Habanero $(\mathrm{F}-\mathrm{H})$ & $8.07 \mathrm{a}$ & $2.17 \mathrm{a}$ & $0.68 \mathrm{c}$ & $2.17 \mathrm{c}$ \\
Habanero $(\mathrm{G}-\mathrm{H})$ & $8.81 \mathrm{a}$ & $2.02 \mathrm{a}$ & $0.82 \mathrm{c}$ & $2.69 \mathrm{c}$ \\
Habanero $(\mathrm{H}-\mathrm{H})$ & $1.47 \mathrm{~b}$ & $2.55 \mathrm{a}$ & $3.91 \mathrm{a}$ & $6.22 \mathrm{ab}$ \\
Habanero/ $\mathrm{N}(\mathrm{H} / \mathrm{N}-\mathrm{H} / \mathrm{N})$ & $3.30 \mathrm{~b}$ & $1.55 \mathrm{a}$ & $3.08 \mathrm{ab}$ & $6.70 \mathrm{a}$ \\
\hline
\end{tabular}

'Quality Groups: Fxcellent $=0 \%$, High $=1$ to $25 \%$, Medium $=26$ to $50 \%$, Poor $=51$ to $100 \%$.

${ }^{2} \mathrm{H}=$ Habanero, $\mathrm{K}=$ Kinabayo, $\mathrm{F}=$ Florido, $\mathrm{G}=$ Gunung, Habanero/ $\mathrm{N}=$ Habanero with aldicarb 10G ( $33.62 \mathrm{~kg} / \mathrm{ha})$.

${ }^{3}$ Means in the same column followed by a common letter do not differ significantly at $\mathrm{P} \leq$ 0.05 according to Duncan's Multiple Range T'est. 
TABI.E 4.-Mean yicld of morhetable and non-markelable tubers of Dioscorea rotundata grouped by dry-rot damage after the second cycle of a rotation experiment with yam cultivars.

\begin{tabular}{lcccc} 
& \multicolumn{4}{c}{ Yield (t/ha) } \\
Treatment ${ }^{2}$ & Marketable & Non-marketable & Total & Loss (\%) \\
\hline Habanero $(\mathrm{K}-\mathrm{H})$ & $9.67 \mathrm{a}^{3}$ & $5.29 \mathrm{~b}$ & 14.96 & 35.4 \\
Habanero $(\mathrm{F}-\mathrm{H})$ & $10.25 \mathrm{a}$ & $2.85 \mathrm{~b}$ & 13.10 & 21.8 \\
Habanero $(\mathrm{G}-\mathrm{H})$ & $10.83 \mathrm{a}$ & $3.51 \mathrm{~b}$ & 14.34 & 24.5 \\
Habanero $(\mathrm{H}-\mathrm{H})$ & $4.02 \mathrm{~b}$ & $10.13 \mathrm{a}$ & 14.15 & 71.6 \\
Habanero/ $\mathrm{N}(\mathrm{H} / \mathrm{N}-\mathrm{H} / \mathrm{N})$ & $4.85 \mathrm{~b}$ & $9.77 \mathrm{a}$ & 14.62 & 66.8 \\
\hline
\end{tabular}

${ }^{1}$ Marketable $=$ excellent $(0 \%)$ and high $(1-25 \%)$ quality tubers; Non-Marketable $=$ me, dium $(26-50 \%)$ and poor $(51-1.00 \%)$ quality tubers

${ }^{2} \mathrm{H}=$ Habanero, $\mathrm{K}=$ Kinabayo, $\mathrm{F}=$ Florido, $\mathrm{G}=$ Gunung, Habanero $\mathrm{N}=$ Habanero with aldicarb $10 \mathrm{G}(33.62 \mathrm{~kg} / \mathrm{ha})$.

${ }^{3}$ Means in the same column followed by a common letter do not differ significantly at $\mathrm{P} \leq$ 0.05 according to Duncan's Multiple Range 'Test.

sented a loss increase of 25.9 and $41.7 \%$ from the first to the second cycle, with and without nematicide, respectively. With rotation of $D$. alata cultivars, yield losses ranged from only 21.8 to $35.4 \%$ in the second cycle. Oramas et al. (1990) reported 93.3 and $67.9 \%$ yield losses of nonmarketable tubers attributable to dry-rot disease for Utuado and Corozal, respectively. According to Román et al. (1980), the dry-rot dis. ease may cause yield losses as high as $98 \%$ in highly infested fields.

From the results of this two-cycle rotation test, it can be concluded that the use of $D$. alata nematode-resistant cultivars as rotation crops significantly improved quality of $D$. rotundata by reducing the incidence of dry-rot. Additional research is needed to determine the effect of increasing the number of cycles of D. alata cultivars, before replanting $D$. rotundata, on quality and yield improvement of cv Habanero. The dry-rot management alternative by rotation of susceptible and resistant Dioscorea species or cultivars would permit growers to grow and market high quality yams all year round. This environmentally acceptable practice will result in better use of the land and higher incomes.

\section{LITERATURE CITED}

Acosta, N. and A. Ayala, 1975. Pathogenicity of Pratylenchus coffece, Scutellonema bradys, Meloidogyne incognita and Rotylenchulus reniformis in Dioscorea rotundata. J. Nematol. 71:1-6.

Ayala, A. and N. Acosta, 1971. Observations on yam (Dioscorea alata) nematodes. Nematropica 1:39-40.

Christie, J. R. and V. G. Perry, 1951. Removing nematodes from soil. Proc. Helminihol. Soc. Wash. 182:106-108. 
Cody, R. P. and J. K. Smith, 1997. Applied Statistics and the SAS Programming Language, 4th ed. Prentice Hall, New Jersey, $445 \mathrm{pp}$.

Departamento de Agricultura, 2001. Compendio Estadístico del Ingreso Bruto Agrícola 2001. Oficina de Estadísticas Agrícolas. Estado Libre Asociado de Puerto Rico, San Juan, PR. 67 pp.

Estación Experimental Agrícola, 1997. Conjunto tecnológico para la producción de raices y tubérculos. U.P.R., R.U.M. C.C.A. Est. Exp. Agric., Publicación 101, 34 pp.

González-Vélez, A. and M. A. Santiago-Córdova, 1989. Rendimiento y resistencia a la antracnosis de 5 cultivares de name, Dioscorea rotundata Poir in Lam. J. Agric. Univ. P.R. 73: 381-382.

Hepperly, P. R. and F. Vázquez, 1989. Tropical yam (Dioscorea spp) performance in Western Puerto Rico. J. Agric. Univ. P.R. 73:133-139.

Martin, F. W. and S. Sadik, 1977. Tropical yams and their potential. Part 4. Dioscorea rotundata and Dioscorea cayenensis. ARS, U.S.D.A., Agriculture Handbook No. 502, $36 \mathrm{pp}$.

Mignucci, J, S., P. R. Hepperly, J. Green, R. Torres-López and L. A. Figuteroa, 1988. Yam production: Anthracnose, yield and profit of monoculture and interplanting. $f . A g$ ric. Univ. P.R. 72: 179-189.

National Academy of Sciences, 1980. Control de Nematodos Parásitos de Plantas. Vol IV, Editorial Limusa, S.A., Mx, 219 p.

Oramas, D., J. Rodríguez and A. L. González, 1990. Effect on yam (Dioscoreu rotundata Poir) of soil spray and seed treatments with the nematicide-insecticide oxamyl L. and soil treatments with phenamiphos 15G. d. Agric. Univ. P.R. 74:103-110.

Román, J, 1978. Filonematología 'l'ropical. Universidad de Puerto Rico, Est. Exp. Agric., $256 \mathrm{pp}$.

Román, J. and J. Badillo, 1965. Response of sugarcane nematode population to addition of nematicides in irrigation water. J. Agric. Univ. P.R. 49: 325-330.

Roman, J., D. Oranas and J. Green, 1980. Investigations on the control of yam (Dioscorea rotundata) nematodes. Nematropica 10:71-72.

United States Environmental Protection Agency, 1996. Food Quality Protection Act (FQPA), Government Printing Office, Public Law 104-170.

West, J., 1934. Dry rot of yams. Bull. Imp. Inst. 32:448-450. 